\title{
Prepositional Word Combinations with modal meaning
}

\author{
Monika Hornacek Banasova
}

DOI: 10.18355/XL.2018.11.03.05

\begin{abstract}
Common Word Combinations vary considerably in terms of structure and meaning. This article is focused on the area of lexical-syntagmatic combinations of Common Word Combinations with functional words. The article also deals with a kind of Common Word Combinations that up to present day has been rather neglected: binary combinations of prepositions and noun. Out of all the possible syntactical positions of the combination between prepositions and nouns, the ones being used as adverbials with modal meaning on the epistemic level were selected. The reason for this being their formal and content-related qualities and the fact that they can be counted as regular ways to express modality which have not received too much attention so far. The empirical analysis of Common Word Combinations is based on methods of Corpus Linguistics and offers verified results concerning usage, possible collocations, variations of meaning and possible equivalents of German preposition-nounconnections in contrastive comparison to Slovak.
\end{abstract}

Key words: common word combinations, set prepositional expressions, means of expressing modality, Corpus Linguistics, epistemic modality

\section{Introduction}

The goal of VEGA-project 1/0037/17 "Contrastive Analysis of Common Word Combinations and Common Constructions in German and Slovak," presided by Prof. Peter Durco is the analysis of prepositional word combinations. This analysis is at the joint between Lexicology, Phraseology, Constructional Grammar, Corpus Linguistics, and Lexicography. The necessity to research the combinatorics of prepositions can be derived from the empirical knowledge that functional words are a lot more restricted in their use as it was perceived until recently in regard to their lexical-syntagmatic combinatorics. Dealing with the topic of Prepositional Word Combinations (PWC) constitutes a profound desideratum in German-Slovak contrastive research on collocations.

A systematic and empirical analysis of common PWCs has been rather neglected up to now. Some studies have been conducted on the matter, PWCs are only treated as a side-matter in these. Di Meola (2014) describes PWC as "prepositional phrases" in his work on the grammaticalization of German prepositions. He treats them from the point of view of prepositions, that is as prepositions in the shape of a syntactical structure. For the purposes of a formal analysis, Di Meola postulates two criteria to determine the level of grammaticalization of a prepositional phrase: the morphosemantic weight (especially the distance towards univerbation) and the decategorization (particularly the morphological invariability, which can be recognised by the lacking possibilities of extension or substitution) (cf. Di Meola 2014: 109 f.). Moreover, the author establishes that another characteristic for these prepositional phrases, which are not used with an article, is the higher amount of grammaticalization. With the analysis of the project being focussed exactly on this sort of PWCs, it seems fair to claim that the object of our analysis is grammaticalized word combinations.

Kiss (2010) focussed on the conditions for the omission of articles in combinations of prepositions and nouns. He establishes that this kind of word combinations are being ignored or described as exceptions at best by grammars, even though they are created

XLinguae, Volume 11, Issue 3, June 2018, ISSN 1337-8384, eISSN 2453-711X 
in conformity with rules. In the context of article-omission, the author also refers to the countability of nouns and defines factors on a structural level and on a content level which take influence on the omission of articles. Of great importance is the finding that both factors interact, thus referring to the importance of the semantics aspect of prepositions - and not only that of nouns - in the context of PWCs ${ }^{1}$. Without going into more detail, he proves the syntactic function of the respective PWC within a sentence. Sentences do have, however, great importance for the PWC itself, as it is possible to deduct the intended meaning of a lexeme as well as of the PWC only in the context of the whole sentence - sometimes exclusively in the context of a whole sentence. $^{2}$

The rare number of contributions or studies shows that it is of utter importance to describe PWCs in a systematic manner.

\section{Empirical Analysis of PWC}

The empirical inquiry of data is based on the methods of Corpus Linguistics. This provides access to large numbers of language data and to extract precise and reliable and verifiable results by using modern corpus linguistic technology.

The database for the analysis of PWC is the online format PREPCON, developed by the project "common Word combinations" under the supervision of Kathrin Steyer (Institute for German Language, Mannheim). PREPCON deals with the phenomenon of PWCs in different depths of description and allows the path from corpus-based empirical data inquiry to a pedagogical lexicographic description comprehensible. The concept of PREPCON is based on the perception that the lexicographic compilation of common word combinations and of lexical patterns cannot be conducted according to a well-established, never-changing grid. Instead, the detection of PWCs needs to be data-oriented, dynamic and flexible by operating on different depths of description in order to meet the requirements posed by the complexity of these linguistic phenomena. ${ }^{3}$

The first module of PREPCON available is the fully automated database in OWID ${ }^{\text {plus }}$, which documents the absolute and relative frequencies of German PWCs with an internal root. The database serves as an exhaustive compilation of a small section of language and thus primarily gains its value by documenting language. ${ }^{4}$ It delivers thus basic information on the common use of Preposition-Noun-Connections.

This basic information is processed further within the project, which means that the PWC is undergoing a collocations analysis. The base corpus is the German Web Corpus "deTenTen 13 in Sketch Engine". Every individual aspect of use in which the

${ }^{1}$ Based on a number of empirical studies, Kiss (2010) develops an inventory of interpretation features. The five main features are: spatial, temporal, causative, modal and existence. These consist of further subcategories: state, comitative, difference in quality, part-taking, subordination, attribution, interrelation, rank, shortfall/transgression, point of reference, topic, recipient, substitution/replacement, exchange, comparative, restrictive, copulative, adversative, distributive, statement, agent, realization.

${ }^{2}$ For the role of the sentence, that is the context and its importance for the extraction of meaning especially of verbs, compare also: Frastikova $(2014,2015)$.

${ }^{3} \mathrm{PWCs}$ in contest (PREPCON): http://uwv.ids-mannheim.de/prepcon/index.html

${ }^{4} \mathrm{http} / /$ uwv.ids-mannheim.de/prepcon/modull/weiterfuehrend.html. This data base is relying on the empirical inquiry of the project Common Word Combinations, looking into 60 German prepositions and their noun in immediate postposition. For every preposition in the data base users can retrieve all nouns occuring in post position in the archive of TAGGED-T. This includes data on the absolute and relative frequency and up to $25 \mathrm{KWICS}$ randomly selected.

${ }^{5} \mathrm{https}$ ://www.sketchengine.co.uk/ 
respective PWC occurred was analyzed, including restrictions on formal level or the partnering words with which collocations are formed. Moreover, the syntactic role of the PWC within a sentence was being looked into, that is whether the PWC is operating in functions other than adverbial ones. ${ }^{6}$

The contrastive analysis with Slovak forms the second part of the corpus analysis and shows a variety of results. The empirical analysis of PWCs consequently is carried out by means of contrastive co-occurrence profiles which are the result of contrastive processing of single aspects of usage.

\section{Modal PWCs}

The reason for looking into PWCs in modal meaning is not only personal interest of the author. These word combinations show very specific formal and content-related qualities which need to undergo a detailed analysis.

Modal meaning is a very broad concept; thus for the current intents and purposes, it will be narrowed down to PWCs in relation to speaker attitude. It is precisely those PWCs that go beyond the formal-semantic qualities of other PWCs in modal meaning, ${ }^{7}$ because they are not used in the adverbial function (as an adverbial supplement $)^{8}$, which means they are not referring to one single word but to the whole content of the sentence. They thus do not operate as parts of a sentence but work via the proposition of the sentence. Those are the most important reasons why a thorough investigation is deemed necessary.

The speaker attitude is connected with epistemic. Meaning on the epistemic level is referring to truth functions. For epistemic language units, the base of modality is comprised of those propositions which are deemed to be known. That is, modal sentences on the epistemic level are based on the grounds of modality that are located in spheres where all propositions are true (Abraham, 2009: 254). Their goal is to explain the truth claims within the statements of a speaker and to convince the recipient of the truthfulness and appropriateness of the expression and to confirm the appropriateness and correctness of the predication "is true" and thus the truthfulness of the statement towards the recipient. The speaker finds himself instigated to explicitly comment on the grade of certainty of his statement.

Helbig/Helbig (1990: 56) distinguish in the context of speaker attitude between the quality of [epistemic] for an attitude of knowledge towards the expressed contents whereas the quality of [doxastic] for attitudes of belief towards the expressed contents. This contribution focusses on PWCs with an indicator for certainty. This is due to an empirical analysis, which showed that PWCs in the meaning of commenting are surprisingly frequent in their appearance (cf. the results in chapter 6). The following PWCs, which all can also be seen as indicators of certainty, are subject of analysis:

außer Frage (beyond debate)

außer Zweifel (beyond doubt)

mit Abstand (by far)

mit Sicherheit (with certainty)

\footnotetext{
${ }^{6}$ For the role of usefulness of corpus linguistic methods in the analysis of phrasemes compare also: Dinzikova (2018). By Barbaresi - Hein (2017) grounds the detection method of german phrasal compounds on a morphological compound analysis operating on token level.

${ }^{7}$ The concept by Kiss (2010) which was described in Footnote (2) distinguishes the „statement" as a aspect of interpretation on its own.

${ }^{8}$ Due to this, PWCs in the meaning indicators for speaker attitude evade other PWCs, which function as adverbial supplements for the time being.
}

XLinguae, Volume 11, Issue 3, June 2018, ISSN 1337-8384, eISSN 2453-711X 


\section{ohne Frage (without question)}

ohne Zweifel (without a doubt)

Their uniqueness has been pointed out before. The in-depth collocational analyses of these PWCs reveals in a further step the specifics of the use of these independent constructions. Based on these findings, those PWCs can be seen as a further means to express modality.

\section{Modal PWCs and the ways of expressing modality}

Languages offer a number of variants to express the same content. Language variation is dependent on many linguistic and extralinguistic factors. Especially comparable semantics or equivalent pragmatic functions form the basis of accordance. The wide area of linguistic modality does have a broad inventory of expressions. Probably the most objective and context-independent criterion for the classification of expressions of modality is based on formal definability. In this manner, specific qualities on the level of morphology, syntax and/or semantics can be described in reference to individual parts of speech or word classes (modal verbs, adverbs, modal words, particles). Various authors point out, however, that a systematic classification of the ways to express modality is yet to be found, as drawing the lines between categories is challenging and most probably not conductible in a precise matter (e.g., Hirschmann, 2015: 23f.). Modality itself is not being described in a uniform way. Abraham (2009: 251) stresses that some grammar books do not even define the term modality or that they apply the propositional mode which, in contrast to the mode of factuality, does not refer to reality. "In German [...] the terms are captured by elements in a list and consequently contribute only implicitly to a thorough conceptual understanding by listing more or less exhaustively at best, and at worst, they do not contribute at all."

In general, the lexical means to express modality are comprised of core parts of speech such as modal verb, modal adverb, and modal particle. In the context of describing the individual parts of speech, the modal meaning is mentioned; this is, however, more aimed at listing the formal and content-based qualities without referring to the link with other modal expressions.

This contribution will focus on the question if and in what way prepositional word groups are mentioned as possible modal expressions in the most dominant grammar books. This does not necessarily involve the description of each individual lexical means of modality.

In most German grammar descriptions, PWCs are not mentioned at all in the context of modality. Sommerfeld/Starke (1998: 74) also includes "modal expressions" along with modal verbs, modal words, particles, and adjectives. These expressions are for example: in der Tat (in fact), aller Wahrscheinlichkeit nach (in all probability), meines Erachtens (in my view). In the context of sentence adverbials, ${ }^{9}$ Zifonun et. al. (1997: 1127) also lists "prepositional word groups" such as zum Glück (to our luck), mit Sicherheit (in all certainty), ohne Zweifel (without doubt), mit Notwendigkeit (of necessity) alongside with adjectives or modal particles.

Helbig/Buscha (1998: 512) do not directly mention PWCs, but they list "prepositional groups" as rivalling forms. Apart from examples such as dem Anschein nach (by all appearances), ohne Zweifel (without a doubt) they also mention prepositional word groups which do not have a direct lexical equivalent among modal words (meinem

\footnotetext{
${ }^{9}$ In this grammar book, modal words are not treated as a part of speech on its own but in connection with modal sentence adverbials they are treated as assertive sentence adverbials. The dispute within linguistics as to whether modal words form a part of speech on their own or whether they are to be seen as a subclass of sentence adverbials would fill another contribution and thus is let out. For the time being, modal words are defined in accordance with Helbig (1990) as a part of speech on their own or as a word class on their own, respectively.
} 
Erachten nach (in my understanding), nach meiner Ansicht (in my view)). The set of problems around PWCs is not an issue, however. On the other hand, the authors did assign the same characteristics by using the PWC ohne Zweifel (without any doubt) to paraphrase the modal word zweifellos (doubtless), but without including a direct link to PWCs.

The overview of grammar books shows that PWCs in modal meaning are mentioned in some works, but only as a note on language variation on the field of linguistic modality. The close look into the modal expressions in the selected grammar books has illustrated the similarities in the way of how modal PWCs and modal words work. For this reason, a comparison of the qualities of modal PWCs and of modal words will be conducted on the following pages.

\section{Modal PWCs and modal words}

Most grammar books mention the examples of PWCs mention mostly in connections with modal words and their rivalling forms. In this respect, the analysis will inevitably have to compare the qualitites of modal words with those of PWCs.

Modal words are defined by their communicative purpose rather than by their conceptual meaning. Consequently, they are separated in various approaches from adverbs and formed a word class respectively a part of speech on their own, according to some linguists. They express a situation-based comment of the speaker on the content of the statement, and they do not signify, similarly to modal particles, a process in extralinguistic reality. Modal particles, as well as modal words, have one aspect of communicative function in common: the speaker can position himself towards his statements in various ways. Owing to these qualities, a tendency becomes visible which consists in a contradiction of logical-grammatical and communicativegrammatical parts of speech. This separates modal words into a part of speech on its own. ${ }^{10}$ At the same time, they are assigned a close relation between the modal particle and the adverbial. In relation to morphology, position and distribution the qualities of modal words are merely different to adverbs, but they are different in their semanticsyntactic relations (cf. Sommerfeld/Starke 1998: 47).

Based on the corpus analysis of modal PWCs, the following questions can be asked about the qualities of modal PWCs:

- Can modal PWCs be replaced by an adverb?

- Do modal PWCs links themselves primarily to the verb in a sentence?

- $\quad$ Are modal PWCs identifiable by questions (similar to adverbs)?

- Is their position in the sentence strictly governed?

${ }^{10}$ In some approaches, modal words are considered to be a subclass of adverbials. "Adverbial" signifies a syntactic function. The term is derived from the adverb, to distinguish thoroughly between categories and functions (cf. Pittner 1999: 46). The view of the author sees the abundance of subclassifications as terminologically complicated, as in connection with modal adverbials, a distinction between adverbials which are connected with processes or events or which are part of an event would be necessary. Moreover, (modal) sentence adverbials- except for adverbials transporting subject attitude - are considered to be a buclass of its own, which express the speaker's attitude. These approaches assume that sentence adverbials with adverbs hve important features such as uninflectability and preposition in sentences (cf. Pittner 1999, Kosta 1998, Eroms 2006). Further implementations will show that modal words and modal PWCs have a lot in common which is the reason why the author refrains from terminological variety and rather focusses in modal words as a part of speech of its own.

XLinguae, Volume 11, Issue 3, June 2018, ISSN 1337-8384, eISSN 2453-711X 
On first sight the three most important qualities of PWCs become obvious - they cannot form clauses, and they do not form a part of a sentence. Because of this, they do not refer to one word within a sentence, but on the contents of the sentence and they cannot be identified with questions and they cannot be negated. ${ }^{11}$ Modal words (MW) have the same qualities. Thus they are being analyzed in detail.

Helbig/Helbig (1990) describe the syntactic qualities of MW in the most detailed way in their Dictionary of German Modal Words. They also focus on those characteristics which separate MWs from modal adverbs. They are the role model for this contribution, and consequently, this contribution uses their examples extended by those retrieved from the corpus. The following list will only include the relevant qualities of modal words whereas those qualities that do not concern PWCs (comparability of MW) will be left out. The main goal is to compare the qualities of MW with those of modal PWCs and to show how similar they are.

The syntactic features of MW are described by Helbig/Helbig (1990: 18 ff.) as "operational criteria for the detection of MW."

1) In contrast to modal adverbs, MWs can be transformed into a superordinate matrix sentence (which contains a lexically matching verb, adjective or participle instead of the MW).

Er kommt vermutlich. (MW) (He will come, presumably).

$\rightarrow$ I deem it probable (it is deemed probable, it is probable) that he will come.

Er kommt wahrscheinlich. (MW) (He will probably come).

Mit Sicherheit / Ohne Zweifel kommt er. (modal PWC)

(With certainly / without doubt, he will come)

$\rightarrow$ It is certain that he will come / I have not doubts that he will come.

Er kommt regelmäßig. (Adverb) (He comes regularly)

$\rightarrow \quad *$ It is regularly, that he comes.

2) MW can be paraphrased by a "Switch-sentence" (parenthesis):

Er hat den Zug vermutlich nicht erreicht. (He presumably did not catch the train.)

$\rightarrow$ He did not - I presume - catch the train.

Er hat den Zug mit Sicherheit nicht erreicht. (He did not catch the train with certainty.)

$\rightarrow$ He did not - that I deem certain - catch the train.

3) In a yes-no-question it is possible to answer with a MW on its own but not with a modal adverb:

11 Dielingt (1986: 145) mentions in this context the term of "relative nonnegatability". He presents an example: Peter hat seine Bücher nicht bedauerlicher-, sondern glücklicherweise verkauft. (Peter has sold his books not regrettably but luckily). The modal words can only be contrastively negated and according to the author, the "syntactic reason for this that the constituents form the base sentence and moreover, that they are the facultative constituents of the base sentence which are furthest away from the sentence ending" (ibid.). Thus it would be wrong to imply from similarities on the syntactical surface of adverbs in negations to semantic similarities. When somebody utters a sentence such as the one in the example, "they do no dispute anything, not even, that his conversation partner has a certain attitude; the person only puts his own attitude against that of his conversation partner" (ibid.). These notes make it clear that modal words cannot carry the content matter of the sentence. 
Kommt der Zug?

(Is the train coming?)
Vermutlich. Wahrscheinlich. Leider. (MW)

Presumably. Probably. Sadly.

Ohne Zweifel. Mit Sicherheit. Außer allen Zweifel.

(modal PWC)

Without doubt. With certainty. Beyond any doubt.

*Schnell. *Pünktlich.

*Quickly. *Punctually.

(Adverb)

4) In contrast to 3), it is possible to inquire about modal adverbs by interrogatives. With MWs, however, this is not possible:

Wie kommt er?

How is he coming?

\section{Schnell. Pünktlich.}

Quickly. Punctually.

*Vermutlich. *Wahrscheinlich. *Leider.

*Presumably. *Probably. *Sadly.

*Ohne Zweifel. *Mit Sicherheit. * Außer allen Zweifel.

* Without doubt. *With certainty. *Beyond any doubt.

5) Some MVs are - in contrast to modal adverbs - not usable in interrogative sentences, in imperative sentences and in irreal sentences:

Kommt er schnell /pünktlich?

*Kommt er mit Sicherheit /ohne Zweifel?

Komm schnell / pünktlich!

*Komm mit Sicherheit / ohne Zweifel! doubt!

Käme er doch schnell / pünktlich!

*Käme er doch mit Sicherheit / ohne Zweifel!
Is he coming quickly /punctually?

*Is he coming with certainty/ without doubt?

Come quickly / punctually!

*Come with certainty/ without

If only he came quickly / punctually!

* If only he came with certainty/

without doubt!

6) The negation word nicht (not) is always positioned before the modal adverb, but after the MW:

Er kommt nicht pünktlich.

Er kommt vermutlich nicht.

Er kommt mit Sicherheit nicht.

He is not coming punctually.

He is probably not coming.

With certainty he is not coming.

Reversing the word order is not permissible in German:

*Er kommt pünktlich nicht.

*Er kommt nicht vermutlich.

*He is coming punctually not.

(*) Er kommt nicht mit Sicherheit. ${ }^{12}$

*He is coming not probably.

*He is coming not with certainty.

The authors would like to point out that a special negation of the adverb is possible, but not of the MWs. The MW itself usually cannot be negated. Cases where it appears to be negated are examples of sentence negation concerning the whole proposition.

Ich vermute, dass er nicht kommt.

I presume that he is not coming.

Ich bin davon überzeugt, dass er nicht kommt. I am convinced that he is not coming.

\footnotetext{
${ }^{12}$ In German, this is considered to be colloquial. In oral communication, it is indeed a possible option.
}

XLinguae, Volume 11, Issue 3, June 2018, ISSN 1337-8384, eISSN 2453-711X 
7) The modal adverb can be substituted by a proword, which is not possible for the MW:

Er kommt schnell. $\rightarrow$ Er kommt so.

Er kommt vermutlich. $\rightarrow *$ Er kommt so.

Er kommt mit Sicherheit. $\rightarrow *$ Er kommt so.
He is coming quickly. $\rightarrow$ He is coming in this way.

$\mathrm{He}$ is probably coming. $\rightarrow * \mathrm{He}$ is coming in this way.

$\mathrm{He}$ is certainly coming. $\rightarrow * \mathrm{He}$ is coming in this way.

8) There is next to no possibility to coordinate MWs, as opposed to modal adverbs:

Er kommt pünktlich und schnell. quickly.

*Er kommt vermutlich und leider.

(!) Er kommt ohne Frage und mit Sicherheit.
$\mathrm{He}$ is coming punctually and

*He is coming probably and unfortunately.

$\mathrm{He}$ is coming without question and with certainty too late.

This is one (and the only) point in which PWCs and MW differ from each other in a significant way. Modal PWC can be coordinated, which is exemplified by following extract from the corpus:

Allerdings ist der Kanzelei Walldorf ohne Frage und mit Sicherheit zu verdanken, dass nunmehr brauchbare Listen von Software erhältlich sind, die sich (lediglich) nach dem Behaupten der Kanzelei zur Herstellung illegaler Kopien eignen.

Engine)

(German Web Corpus deTenTen in Sketch

(However, it goes without any question and is with certainty owing to the law office Walldorf that we have usable lists of software available which are (only) claimed by the law office to be suitable for the production of illegal copies.)

MWs can also be combined according to authors (expecially if they are parts of different subclasses).

Er kommt leider vermutlich (vermutlich leider) zu spät.

(Unfortunately, he most probably will be late.)

Exemplified by following extract from the corpus:

Die Produktion ist rund, klingt nicht zu modern und rundet das Gesamtwerk gelungen ab. Für Freunde melodischer Death/Doom-Kost ohne Frage mit Sicherheit eines der heißersehnten Veröffentlichungen im Frühjahr des Jahres.

(The recording is sound, does not appear to be too modern and gives to finishing touches to the complete work in a suitable way. For friends of melodic Death/Doomrecors, without any question certainly one of the eagerly anticipated releases of this year's spring.)

Eine der wohl bemerkenswertesten Frosch-Arten ist mit Sicherheit ohne Frage der Rotaugen-Laubfrosch bzw. Rotaugenfrosch (wissenschaftlicher Name: Agalychnis callidryas). Durch seine kräftigen Farben ist er in jedem Wohnzimmer das gewisse Etwas. (German Web Corpus deTenTen13 in Sketch Engine)

(One of the probably most recognizeable Frog-species is certainly without any question the red-eyed frog (scientific name: Agalychnis callidryas) Due to his bright colors, the adds a certain classiness to every living room.) 
The extensive description of these qualities shows that modal PWCs have almost identical qualities to the modal words (they only differ insofar as PWCs can be coordinated). MWs and PWCs cannot be part of a sentence on their own, they cannot be negated, and they are used to answer yes-or-no-questions - those are the most important features which form the base for comparing MWs with other parts of speech. Modal PWCs are not distinguished as a part of speech on their own. The author is primarily focussed on the syntactic description of the features of modal PWCs. This syntactic point of view on modal words and the modal PWCs shows, however, that they do not form syntactic foreign words, but that they are resorbed syntactically (Helbig 1984: 105). The morphosyntactic qualities of modal words and of modal PWCs undergo an extensive description in order to create a better understanding on a linguistic level even though they are more interesting from the point of view of semantics. The semantic status of modal words and modal PWCs is different from that of propositions. The syntactic component of the language system eliminates such differences, which makes syntax relatively autonomous of semantics. ${ }^{13}$ This point shows the importance of research in collocations based on a formal description. However, semantic, that is semantic and mainly functional restrictions prove themselves to be the structural qualities over form.

\section{Results of an empirical analysis of modal PWCs}

The problem of modal PWCs can be considered to be a new field of linguistics. Following the theoretical description, we will show the most important results of the empirical investigation. Every scrutinized PWC außer Frage (beyond debate), außer Zweifel (beyond doubt), mit Abstand (by far), mit Sicherheit (with certainty), ohne Frage (without question), ohne Zweifel (without doubt) underwent a detailed collocations analysis which should be able to show the various aspects of usage of the PWC and its formal qualities. The following will not include single results but the most important ones will be presented in a summarized version. This will include first and foremost the comparison of the single PWCs in respect to their formal and functional qualities. This is because all of them have the same meaning, they express the speaker's attitude and function as indicators of certainty within the sentence. The focus will also be on a contrastive analysis with Slovak.

All examples listed are taken from the corpus deTenTen 13 in Sketch Engine.

\section{Gaps in the lexicographical description}

The first results of the corpus analysis show that there are often gaps in the lexicographical description. The most striking one can be found with the modal PWC mit Abstand (by far). With 114398 hits in the corpus, this PWCs is on rank 12 of the list for collocates with the preposition with. Nevertheless, this PWC is not listed in the DUDEN-online-dictionary, ${ }^{14}$ even though it forms a set element of the lexicon. Under "distance," the dictionary lists the following meanings:

1. The physical distance between two points, units; gap; distance

2. The period between two points in time

3. Reluctance, due respect in treating other people, distance

4. (colloquial) indemnity

The last meaning in this list is being excluded, as this is a different variant of usage. The results of the corpus analysis of the PWC mit Abstand (by far) show, however, that there is another, additional meaning to be added, which is not listed in the dictionaries at all:

${ }^{13}$ Cf. Dielingt (1986), Steinitz (1984).

${ }^{14} \mathrm{https}: / /$ www.duden.de.

XLinguae, Volume 11, Issue 3, June 2018, ISSN 1337-8384, eISSN 2453-711X 


\section{Excluding any doubt, being clear and discernible}

The following evidence shows that they are about epistemic meaning:

Wer sich für Bücher mit Engeln interessiert, ist hier genau richtig! Übrigens solltet ihr (falls Interesse besteht) warten bis der 5.Teil erschienen ist, denn das Ende des vierten Teiles ist mit Abstand das gemeinste Ende aller Bücher, die ich je in meinem Leben gelesen habe!

(Those who are interested in books with angels are exactly right here! By the way, you should (if you are interested) wait for the $5^{\text {th }}$ part to be published, as the end of part 4 is by far the meanest ending of books that I have ever seen in my life.)

The speaker finds himself obliged to explicitly comment on the aspect of certainty. This is a confirmation of the appropriateness and correctness of the proposition "is true", which is also a confirmation of the truthfulness of the statements towards the recipient. The modal PWC mit Abstand (by far) can be paraphrased as eindeutig (obvious), and ohne Zweifel (without doubt).

The contrastive analysis shows considerable differences in the usage of these PWCs. Slovak online dictionaries ${ }^{15}$ translate these PWCs as zd'aleka, sodstupom, (s) rozdielom, which are equivalents that refer to the non-epistemic meaning (1-3). An analysis of the PWC s odstupom in the Slovak National Corpus, results in the findings that this PWC only carries non-epistemic variants of meaning:

1. Period between two points in time - the typical collocation sodstupom času (with distance in time) does not have an equivalent in German.

2. Sports: $s$ odstupom $x$ bodov (with a distance of X points)

3. Distance, respect in dealing with other people.

4. Physical distance - this variant is only present in the SNC to a very limited extent.

The analysis in the $\mathrm{SNC}^{16}$ shows that the PWC $s$ odstupom cannot express modal or epistemic meaning. For this variant of usage, equivalents such as jednoznačne, absolútne, bez pochýb (obvious, absolutely, without doubt) can be used in Slovak.

A similar example is the PWC mit Sicherheit (with certainty). In German, this PWC is used for epistemic meaning in connection with a verb, for non-epistemic meaning, adverbs are preferred. Examples such as *mit Sicherheit fahren / auftreten / handeln $(*$ drive/appear/operate with certainty) are very rare in non-epistemic meaning. In Slovak, on the other hand, the PWC $s$ istotou is used for epistemic and non-epistemic meaning, in both usages there are no limitations. These examples show that there are divergences between the two languages or semantic restrictions which are represented in the equivalence of the respective language.

The analysis of PWC mit Abstand (by far) and mit Sicherheit (with certainty) shows that the lexicographical description has gaps. It also shows that equivalence is a single-language phenomenon, as one PWC cannot have a direct equivalent in another language, the usage of a PWC can be limited or even absent in other languages. Based on the concept of equivalence in Durco (2015), this case can be characterized as interlingual extensional divergence. "It is the relationship of incomplete symmetry because one type of opposition on a formal level is facing a related type of opposition on a semantic level. This is the case when two linguistic units that are identical on the formal level to not match each other in their extension of meaning." (Durco, 2015: 111).

\section{The problem of equivalence}

${ }^{15} \mathrm{https}$ ://webslovnik.zoznam.sk, https://slovnik.azet.sk

${ }^{16} \mathrm{https}$ ://bonito.korpus.sk 
Large divergences can be found mainly with modal PWCs in epistemic meaning. As shown in the examples under 6.1, it not necessarily the case that every PWC in German has a direct equivalent in Slovak. Due to the corpus analysis of several PWCs in epistemic meaning, that is of those who express speaker attitude and which are described as indicators of certainty, the divergences can be summarized in the following way:

ohne Zweifel (without doubt)

außer Frage (beyond doubt)

ohne Frage (without question)

außer Frage (beyond debate)

mit Abstand (by far)

bez pochýb / bez pochybností

German has a broad variety of epistemic PWCs used in the meaning of so-called indicators of certainty (vgl. Helbig/Helbig 1990), Slovak, on the other hand, uses, apart from many modal words and particles only the PWC bez pochýb / bez pochybností. Between those two languages, divergence in terms of equivalence is considerable. This binary link between the formal privative opposition and semantic identity is referred to as interlingual formal variability by Durco (2015). „It is incomplete symmetry because one type of formal opposition is faced by a related type of semantic opposition. This refers to cases where semantically identical units differ from each other by the word forms of their components" (Durco, 2015: 113). In German, a lot more epistemic modal PWCs can be observed than in Slovak. As for Slovak the epistemic meanings are not primarily expressed by non-verbal equivalents such as modal words or modal particles. ${ }^{17}$ The only PWC bez pochýb / bez pochybnosti (both PWCs are formal variants with identical meaning: frequency of bez pochýb in the SNC: 486 examples, bez pochybnosti 278 examples) are only listed in the online dictionaries; the Slovak KSSJ ${ }^{18}$ does not mention this PWC at all.

Horvathova/Tabackova (2018:118 f.) describe for example the strategies of the translation of idiomatic phrases and drawing on analysis they discovered major tendencies in the translation ${ }^{19}$.

\section{Restrictions in collocability and equivalence of semantically identical PWCs}

The PWCs listed in chapter 6.2 used in the meaning of indicators of certainty were submitted to a detailed analysis of their collocability and their equivalence. In order to show certain tendencies in the usage of particular PWCs they were compared in pairs:

\section{ohne Zweifel (without doubt) - außer Zweifel (beyond doubt)}

The PWC ohne Zweifel (without doubt) is the fourth most frequently possible joint with the preposition mit (with) (72036 examples). Außer Zweifel (beyond doubt), on the other hand, is on rank 13 with 6700 hits. The collocability of this PWC, however, is restricted. PWC ohne Zweifel (without doubt) joins together with different verbs, it

${ }^{17} \mathrm{Cf}$. The analysis of equivalence of German modal verbs in Banasova (2013), which showed that German modal verbs in epistemic meaning do have mainly non-verbal equivalents in Slovak.

${ }^{18} \mathrm{http}: / /$ slovnik.juls.savba.sk/?w=plagiat\&d=kssj4

${ }^{19}$ For the quality of Google translation of the terms compare also: Cechova-Macura -Kubusova -Janosikova (2017).

XLinguae, Volume 11, Issue 3, June 2018, ISSN 1337-8384, eISSN 2453-711X 
can also be part of an attribute (e.g. die ohne Zweifel auch vorhandene Abhängigkeit der Inhalte von der Person des Experimentators (the without doubt also existing dependence of contents on the person of the experimentator)), it can have an attributive supplement (ganz ohne Zweifel (without any doubt), vollkommen ohne Zweifel (completely without doubt), ohne jeden / allen / jeglichen / einigen / irgendeinen Zweifel (without every / some / most / the slightest doubt)). PWC außer Zweifel (beyond doubt) has only limited options for collocations and is more linked with set collocations: etw. steht außer Zweifel (sth. goes beyond doubt), etw. außer Zweifel setzen (to put sth. beyond doubt), außer Zweifel lassen (to leave sth. beyond doubt):

Der Verfasser dieser Zeilen hatte selber die Gelegenheit, den Inhalt dieser Briefe, deren Glaubwürdigkeit völlig außer Zweifel steht, zu hören und zu lesen.

(The author of these line had the possibility himself to listen to and read the contents of these letters which is in its credibility is beyond any doubt.)

Sechs schwere, zum Teil den Schädel durchdringende, unbedingt tödliche Kopfwunden, und die Umhüllung des über den Kopf gezogenen und dicht über den Knien zusammengebundenen Sackes setzen den Mord außer Zweifel.

(Six heavy wounds, partly perpetrating the skull and in any case deadly head wounds, and the covering of the head by a bag which was tied together closely over the knees put murder beyond doubt.)

Dass er seiner Mannschaft immer so eine Leistung zutraut, hat Hecking nie außer Zweifel gelassen, dass sie es aber konstant anbieten kann, das wird wohl die Frage des jeweiligen Entwicklungsstandes und auch von individueller Qualität sein.

(That he trusted his team with such a performance, was never left beyond doubt by Hecking, that the team could deliver so constantly will be a matter of the state of development and of individual quality.)

Those collocations do not have a direct equivalent in Slovak. In those cases, the predicative je nepochybné or a connection between a verb and a modal particle such as bezpochyby, nepochybne, bezpochýb are used. A possible equivalent could also be niet pochýb (o tom), že... with a relatively high frequency in the SNC (2632 hits), which again is missing in the KSSJ-dictionary.

Based on the analysis of these two PWCs, it is possible to conclude that formal restrictions on the collocability (with identical semantic properties) is a decisive features. The PWC which is more linked to set collocations (außer Zweifel (beyond doubt)) is used less frequently than the PWC with more possibilities of collocation (ohne Zweifel (without doubt)).

\section{ohne Frage (without question) - außer Frage (beyond debate)}

The PWC ohne Frage (beyond debate) forms the $3^{\text {rd }}$ most frequently used example of possible connections with the preposition außer (out of) (32761 hits). Ohne Frage (without question), on the other hand takes rank 27 with 28300 hits. The circumstances are different than with the first pair of expressions. The collociability of the PWC außer Frage (beyond debate) is very restricted. It is mainly limited to the most typical collocation, etw. steht außer Frage (sth is beyond debate):

Es steht außer Frage, daß sich die menschlichen Gesellschaften, ebenso wie der Mensch an sich ein komplexes System darstellen, daß sich an veränderte Lebensbedingungen anpassen kann und sich so sein Überleben sichert. 
(It is beyond debate that human societies as much as the human being itself form a complex system which can adapt to changing living circumstances and thus ensures its survival.)

Contrary to the first pair of PWCs, the collocability of the PWC außer Frage (beyond debate) is very limited. Nevertheless this PWC is on $3^{\text {rd }}$ rank in the list of possible PWCs. The frequency of the PWC ohne Frage (without question), which has more possibilities to form collocations, is lower ranking by contrast. Consequently, formal restrictions in the collocability of PWCs are in comparison to the first pair of PWC not important. Common collocations are more frequently than collocations with a wider array of collocation possibilities.

\section{ohne Frage (without question) - ohne Zweifel (without doubt)}

While examining the collocability of PWCs with the same preposition, it becomes evident that both PWCs have the same collocators and the same collocators in the context of attributive supplementation. Both PWCs can, for example, also be part of an attribute.

Er setzt sich damit nicht (!) absolut, sondern er beruft sich auf ein fundamentales "Recht", sein Leben beenden zu wollen, weil es ihm unerträglich erscheint und er nicht auf die ohne Frage viel versprechenden Erfolge in der Palliativmedizin setzen oder den "kleinen Bruder des Todes" begegnen möchte.

(He does not set himself absolute, but he is claiming a fundamental "right" to end his life because it appears to be unbearable to him and because he cannot put his hopes on the without question promising results of palliative medicine or to meet the "little brother of death".)

Die ohne Zweifel auch vorhandene Abhängigkeit der Inhalte von der Person der Experimentators ist aufgrund der Ähnlichkeit der Muster und der auch bei der ITK vorauszusetzenden psychischen 'Einbindung' nicht verwunderlich, ...

(The without doubt also existing dependence of contents on the person of the experimentor is not surprising due to similarity of patterns and also because of the psychological "involvement" which also has to be expected with ITK...)

These two units have the same formal and semantic collocation qualities. Differences are to be found however in the frequency of both PWCs: ohne Zweifel (without doubt) is ranked fourth in the list of prepositions with 72036 hits, ohne Frage (without question) is ranked 27 with 28300 hits. Due to that, we can conclude that the PWC with the word doubt signifies the basic meaning and thus is used more frequently, whereas the PWC with the word question is used in metaphorical meaning and is thus used less often.

This is also represented in the equivalence. PWC ohne Frage (without question) does not have a direct representation in Slovak; the modal particles bezpochyby, nepochybne, nesporne, or the PWC bez pochýb are used instead, which are all equivalents which include the word doubt [pochyba].

This partial analysis shows that in these cases the semantic component of the collocation (with all formal qualities being the same) is decisive.

\section{außer Frage (beyond debate) - außer Zweifel (beyond doubt)}

A completely different situation can be found between the abovementioned PWCs. Analysing them clearly shows that both PWCs are comprised of the same collocators in general and also as attributes. They have identical formal and semantic collocation qualities with the exception of außer Frage (beyond debate) only occurring with other

XLinguae, Volume 11, Issue 3, June 2018, ISSN 1337-8384, eISSN 2453-711X 
verbs only to a very limited extent. Their collocability is linked to the combination etw. steht außer Frage (sth. is beyond debate) - makes up for $89 \%$ of all verbal collocations:

Nur die Elite der Behindertensportler kämpft bei den Paralympics um Medaillen, das steht außer Frage.

(Only the elite of the physically challenges athletes fight for medals at the Paralympics, that goes beyond debate.)

Es steht außer Zweifel, dass die Angeklagte diesen kleinen Jungen am 5. Februar 1980 tötete.

(It is beyond doubt that the defendant killed these two little boys on 5 February 1980.)

A comparison of the frequency of these two PWC shows that the PWC außer Frage (beyond debate) is used more frequently than the PWC außer Zweifel (beyond doubt) (außer Frage (beyond debate): $3^{\text {rd }}$ rank with 32761 hits; außer Zweifel (beyond doubt): $13^{\text {th }}$ rank with 6700 hits). This is consequently a completely different case than for the PWCs ohne Frage (without question) and ohne Zweifel (without doubt). The contrast between basic meaning versus metaphorical meaning does not play any role here. The PWC außer Frage (beyond debate), in which the base word is used metaphorically [a word-by-word translation of the German would read as beyond any question] is nonetheless used more often than the PWC außer Zweifel (beyond doubt) with the base word in its basic meaning. The analysis consequently shows that in these cases the semantic component in the collocation is not decisive (with the same formal qualities).

The results of the analysis show that the individual PWCs are very restricted in usage and that a number of common tendencies in usage and form are only observable with great difficulty.

\section{Conclusion}

This contribution was aimed at focussing attention on PWCs which serve as another possible means to express modality. Analysing relevant grammar books has shown that this sort of PWC has not undergone any systematic analysis. In general, one has to state that unfortunately, modal PWCs have only received very little attention.

The description of their semantic and morpho-syntactic qualities has revealed clearly that they have almost identical features to modal words. The discussion as to whether modal words are to be seen more as (modal) adverbs had to be excluded as space is restricted. Thus modal words were considered to be a part of speech on their own, and as such, they were compared to modal PWCs functioning as indicators of certainty.

The mere fact that modal PWCs cannot be replaced by adverbs and thus cannot appear in syntax as (modal) adverbial supplement point towards the feature of them having very specific syntactic functions. Further qualities such as the impossibility to negate them, the impossibility to determine them by questions and no primary link to the verb in a sentence distinguish PWC from other parts of speech. Moreover, the PWCs under scrutiny are frequent in usage as shown by the lists of preposition-nouncombinations developed within the PREPCON-project.

The results of all these analyses confirm that modal PWCs should receive more attention on morpho-syntactic as well as on semantic level. The empirical approach sheds new light on this problem. Based on a corpus-oriented analysis, it is possible to look into the usage of PWC in specific constructions. Analysing the collocators of modal PWC has shown that every PWC under scrutiny has specific qualities and that no common tendencies concerning form and usage can be observed.

Another very interesting field in the research is the problem of equivalence. The analysis of particular PWCs confirms that their lexicalization is motivated differently 
in every single language. In comparison with German, Slovak only has very few modal PWCs (modal particles are used instead) used as indicators of certainty, and equivalents do not match semantically either between the two languages. Interlanguage divergences and variability show that there are not very many regularities between languages when it comes to equivalence.

The field of modal PWCs offers a novelty in the area of systematic linguistics, pragmalinguistics, and computational linguistics, as it links (traditional) analysis of lexical expressions of modality with the latest research in common and set word connections which have been present in linguistics only for the last 20 years.

\section{Bibliographic references}

ABRAHAM, W. 2009. Die Urmasse von Modalität und ihre Ausgliederung. Modalität anhand von Modalverben, Modalpartikel und Modus. In: Modalität. Epistemik und Evidentialität bei Modalverb, Adverb, Modalpartikel und Modus / Ed. by W. Abraham, E. Leiss. Tübingen: Stauffenburg (= Studien zur deutschen Grammatik 77), pp. 251-270. ISBN 9783860574683.

BANASOVA, M. 2013. Deutsche Modalverben und ihre Äquivalente im Slowakischen. Berlin: Logos. ISBN 9783832533465.

BARBARESI, A. - HEIN, K. Data-Driven Identification of German Phrasal Compounds. In: Lecture Notes in Computer Science / Ed. By Ekstein K.,Matousek V., vol. Volume 10415 LNAI, pp. 192-200. ISBN 978-331964205-5.

DIELINGT, K. 1986. Zur Subklassifizierung der deutschen Modalwörter. In: Deutsch als Fremdsprache: Zeitschrift zur Theorie und Praxis des Deutschunterrichts für Ausländer, vol. 23, pp. 144-148. ISSN 00119741.

DINZIKOVA, I. 2018. Usefulness of corpus linguistic methods in the analysis of phrasemes in journalistic texts. In: XLinguae, vol. 11, n. 1XL, pp. 347-364. ISSN 1337-8348.

DURCO, P. - STEYER, K. - HEIN, K. 2015. Sprichwörter im Gebrauch. Trnava: Univerzita sv. Cyrila a Metoda. ISBN 9788081056925.

EISENBERG, P. et al. 1998: Grammatik der deutschen Gegenwartssprache. Bd 4. Dudenverlag. ISBN 3411040467.

EROMS, H. W. 2006. Satzadverbien und Diskurspartikeln. In: Dependenz und Valenz. Ein internationales Handbuch der zeitgenössischen Forschung / Ed. By V. Agel, L. M. Eichinger, H. W. Eroms, P. Hellwig, H. J. Heringer, H. Lobin, Berlin: de Gruyter, vol. 2. ISBN 9783110194111.

FRASTIKOVA, S. 2014. Das Valenz-Kollokationssyntgma konverser Verben "mieten" und "vermieten". In: Slowakische Zeitschrift für Germanistik, vol. 6, n. 2, pp. 46-64. ISSN 13380796.

FRASTIKOVA, S. 2015. Das schillernde Positionsverb „sitzen“. Eine kontrastive korpusbasierte Untersuchung des Valenzpotenzials verbaler Lemmata. Berlin: Logos Verlag. ISBN 9783832539399.

HELBIG, G. 1984. Studien zur deutschen Syntax Bd. 2. Leipzig: Verlag Enzyklopädie. ISBN 6307686.

HELBIG, G. - BUSCHA, J. 1998. Deutsche Grammatik. Langenscheidt. ISBN 3324001188.

HELBIG, G. - HELBIG, S. 1990. Lexikon deutscher Modalwörter. Leipzig: Verlag Enzyklopädie. ISBN 3324005507.

HIRSCHMANN, H. 2015. Modifikatoren im Deutschen. Ihre Klassifizierung und varietätenspezifische Verwendung. Tübingen: Stauffenburg (= Studien zur deutschen Grammatik 89). ISBN 9783958095403.

HORVATHOVA, B. - TABACKOVA, Z. 2018. Approaching the translation of idioms through the compensation strategy. In: XLinguae, vol. 11, n. 1XL, pp. 107126. ISSN 1337-8348.

XLinguae, Volume 11, Issue 3, June 2018, ISSN 1337-8384, eISSN 2453-711X 
KISS, T. 2010. Bedingungen für den Wegfall eines Artikels: Distribution und Interpretation von Präposition-Nomen-Kombinationen. In: Sprachliches Wissen zwischen Lexikon und Grammatik / Ed. by S. Engelberg, A. Holer, K. Proost, Berlin: de Gruyter. Available online: http://www.gbv.de/dms/ goettingen/661752208.pdf

KOSTA, P. 1998. Über Argumentstruktur, Fokussierung und modale Satzadverbien im Tschechischen und Russischen. In: Zeitschrift für Slawistik, vol. 43, n. 2, pp. 140154. ISSN 00443506.

di MEOLA, C. 2014. Die Grammatikalisierung deutscher Präpositionen. Tübingen: Stauffenburg. ISBN 9783860574522.

PITTNER, K. 1999. Adverbiale im Deutschen. Untersuchungen zu ihrer Stellung und Interpretation. Tübingen: Stauffenburg. ISBN 3860574507.

ROSTEKOVA, M. 2018. Francuzsko-slovenska spolupraca ako motor internacionalizacie vysokoskolskeho vzdelavania na Slovensku. In Politicke vedy. [online]. vol. 21, n. 1. pp. 204-211. ISSN 1335 - 2741. Available at: http://dx.doi.org/10.24040/politickevedy.2018.21.1.204-211

SOMMERFELD, K. E. - STARKE, G. 1998. Einführung in die Grammatik der deutschen Sprache. Tübingen: Niemeyer. ISBN 3484730013.

STEINITZ, R. 1984. Lexikalisches Wissen und die Struktur von Lexikon-Einträgen. In: Linguistische Studien ZISW/A, vol. 116, pp. 1-88. ISSN 0138-4694.

ZIFONUN, G. et al. 1997. Grammatik der deutschen Sprache, Bd. 3. Berlin: de Gruyter. ISBN 3110147521.

Internet sources

https://bonito.korpus.sk

https://slovnik.azet.sk

https://slovnik.juls.savba.sk/?w=plagiat\&d=kssj4

https://uwv.ids-mannheim.de/prepcon/index.html

https://www.duden.de/

https://slovniky.lingea.sk/nemecko-slovensky

https://www.sketchengine.co.uk/

https://webslovnik.zoznam.sk

Words: 8066

Characters: 52112 (28,95 standard page)

PaedDr. Monika Hornáček Banášová, PhD.

Department of Germanistics

University of Ss. Cyril and Methodius in Trnava

Nam. J. Herdu 2, 91701 Trnava

Slovakia

monika.hornacek@ucm.sk 